\title{
Crime and its Punishment in Victorian Hong Kong
}

Le crime et son châtiment à Hong Kong à l'époque victorienne

\section{Alain Le Pichon}

\section{(2) OpenEdition}

\section{Journals}

Electronic version

URL: http://journals.openedition.org/rfcb/1613

DOI: $10.4000 / \mathrm{rfcb} .1613$

ISSN: 2429-4373

\section{Publisher}

CRECIB - Centre de recherche et d'études en civilisation britannique

\section{Printed version}

Date of publication: 1 September 2003

ISSN: 0248-9015

\section{Electronic reference}

Alain Le Pichon, «Crime and its Punishment in Victorian Hong Kong », Revue Française de Civilisation Britannique [Online], XII-3 | 2003, Online since 01 September 2003, connection on 01 May 2019. URL : http://journals.openedition.org/rfcb/1613; DOI : 10.4000/rfcb.1613

This text was automatically generated on 1 May 2019.

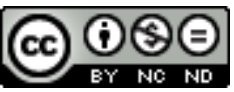

Revue française de civilisation britannique est mis à disposition selon les termes de la licence Creative Commons Attribution - Pas d'Utilisation Commerciale - Pas de Modification 4.0 International. 


\title{
Crime and its Punishment in Victorian Hong Kong
}

\author{
Le crime et son châtiment à Hong Kong à l'époque victorienne
}

\author{
Alain Le Pichon
}

1 With the ratification of the Treaty of Nanking in 1843, the island of Hong Kong, which had first been occupied by the British two years before, acquired legal existence as a British colony. The future and viability of the new colony, however, were far from secure. Economic activity was in its infancy, but crime already flourished. Official dispatches to the Foreign Office bemoaned the 'complete unimportance' of the settlement, its mercantile inactivity, and 'the sad mistake committed by Sir Henry Pottinger in choosing for a British Settlement an island as barren as Hong Kong.' ${ }^{1}$ There was no indigenous activity to speak of in Hong Kong, apart from a few small fishing and farming communities. The Chinese who initially came to the Colony belonged to the vagrant population roaming the waters of the Pearl River delta. The early observers and chroniclers of the Colony all concurred that there was 'not one respectable Chinese inhabitant' in Hong Kong. ${ }^{2}$ The early local settlers were 'the refuse of the [Chinese] population'. Some observers even felt dutybound to add that the landscape of the island was in perfect harmony with the moral characters of its inhabitants, its hills being 'of a greenish hue, like a decayed Stilton cheese' and presenting 'the appearance of a negro streaked with leprosy'. ${ }^{3}$ As the settlement grew into a busy Victorian city, the colony dubiously acquired by Britain as one of the rewards for winning an opium war developed baffling forms of criminality. There were pirates who killed entire ship crews for a handful of Spanish dollars; women who stole girls for domestic service; prostitutes who were pushed out to die in the streets in order to avoid bringing their brothels bad luck.

In the absence of any synthetic study on the subject of criminality in Victorian Hong Kong, the need exists for a general survey which could delineate the tortuous path followed by the British colonial system as it muddled its way through the imperial century. Local practice often contradicted legislation at home. The need to punish could conflict with attempts to reform offenders. Preconceived ideas about punishment were sometimes rigidly applied, and at other times experimentation and pragmatism were 
allowed to prevail. The aim of this paper is to contribute an exploration of the elements which a full survey would need to assemble and analyze.

\section{Police returns, 1873-1882}

3 The first set of Hong Kong statistics on the Colony's criminal activity were published in 1883 and cover the decade 1873-1882. Two documents are of particular interest: Notification $\mathrm{N}^{\circ} 52$, 'Returns from the Victoria Goal', and Notification $\mathrm{N}^{\circ} 83$, 'Police Returns'. ${ }^{4}$ The Police Returns make a distinction between 'Serious offences' and 'Minor offences,' - the latter including 'Assault', 'Gambling', 'Drunkenness', 'Nuisances', 'No pass or light', and 'Miscellaneous'. Leaving aside the large but amorphous 'Miscellaneous' category, the largest class of offence - with 1,007 annual occurrences on average between 1873 and 1877, (or close to three a day) - was 'No pass or light'. Until 1896 a Chinese walking about after dark without his pass or light was committing a criminal offence, regardless of his intentions, and could therefore be arrested. The other categories of 'Minor offences' - 'Assault' (without intent to rob, and without grievous bodily harm), 'Gambling', 'Drunkenness', 'Nuisances' - all refer in one way or another to the kind of general disorderly behaviour usually associated with poverty, habits of immorality, or both, which enabled a Victorian policeman to arrest suspicious characters.

The largest category in the list of Serious Offences is labelled 'Larcenies'. In the Colony of Hong Kong there were on average 1,016 annual instances of this crime between the years 1873 and 1877, and 1,877 instances between 1878 and 1882. This equates roughly to five detected 'Larcenies' a day, of which two-thirds led to arrests. The term 'Larceny' does not, however, exhaust the category of theft. To 'Larceny' should indeed be added the other sub-classes of the same crime which, in order of increasing seriousness, included: 'Unlawful possession', 'Assault with intent to rob', 'Burglaries and Larcenies in dwelling', and 'Robbery with violence'. When taken all together, these crimes occurred at the average rate of 6.34 a day between the years 1878 and 1882. This prevalence of robberies can best be appreciated when compared with all other criminal acts listed under 'Serious offences' ('Murders', 'Kidnapping', 'Piracy', and 'Felonies not already given') which occurred at the daily rate of 0.26 per day. This is a clear indication that in the Colony of Hong Kong as had been the case in Britain in the earlier part of that same century,

The prime concern of those who sought to impose the law was not the protection of life and limb, but the protection of property very often of an inconsequential nature. It was in the realm of petty theft that the magisterial mind chose to set up the crucial boundary between acceptable and criminal behaviour [...]. ${ }^{5}$

The crime of 'Kidnapping', however, occurred with remarkable frequency. Between 1873 and 1877, no fewer than 345 cases were reported, making it the second most frequent criminal offence in the colony after the various classes of 'Robberies'. A distant colony where a case of kidnapping was reported every five days was not unlikely to strike the minds of officials back home as highly anomalous. Many years were to elapse before the cultural roots of the problem could be understood and appropriate remedial measure taken against the offenders. 


\section{Gaol returns}

6 Notification $\mathrm{N}^{\circ} 52$ of the 1882 Hong Kong Colony's Administrative Reports give statistics on the prisoners in the Victoria Gaol only for the year 1882. The imbalance in numbers between the European and the Chinese inmates is striking. There were a total of 717 prisoners at the end of January 1882, 563 at the end of June and 532 at the end of December; but the respective distribution between European and Chinese was the following: 72 Europeans vs. 645 Chinese in January; 27 vs. 536 in June; and 34 vs. 498 in December. This ethnic imbalance in the numbers was therefore a structural feature of the criminal population in the Kong Kong Colony. Of the total amount of offenders who served prison sentences during that year, between $5 \%$ and $10 \%$ were indeed Europeans (British for the most part), and 90 to $95 \%$ were Chinese. In 1865, the Colony had a total population of 126,000 , of which the Chinese element represented $97 \%$ and the British and non-Chinese only $3 \%{ }^{6}$ If anything, therefore, the returns broadly suggest that the colonial system of criminal retribution treated the Europeans and the Chinese evenhandedly.

7 The second table provides a more detailed picture of criminal activity in the Colony from which the following facts emerge. Of the 3,498 individuals who spent some time in the Victoria gaol in 1882 , as many as 520 , or a full $15 \%$, had not yet been sentenced and were 'On remand for trial or pending orders'. There were also 34 prisoners in the gaol for the crime of simply being in debt, an offence which had been decriminalised in England as far back as 1838.7 A similar number were in prison for 'Mendicancy'. Four were jailed for 'Uttering threats', and two for 'Breach of the Brothel Ordinance', etc. The number of prisoners was also relatively insignificant for offences such as 'Perjury and Contempt of Court' (14), 'Extortion' (3), 'Uttering counterfeit coins or notes' (9), 'Embezzlement' (1). The much larger battalions of prisoners were in the Victoria gaol for offences connected in one way or another with stealing, or behaviour associated with poverty, vagrancy, or breaking of Ordinances designed to ensure a modicum of public peace. Close to 1,200 had been sentenced for various forms of 'Larceny' and 'Robbery'; 384 for 'Common Assault, fighting, and disorderly behaviour'; 685 for 'Breach of the Gambling Ordinance, [for being] Rogues and Vagabonds, suspicious and dangerous characters'; 526 for 'Unlawful hawking or selling goods without licence, without passes or light, obstructing, breach of the Opium registration Ordinance'. Altogether this class of prisoners - the thieves, the robbers, the pilferers, the marauders, and the petty defrauders of government by way of breaking the gambling or opium divans rules - represented no less than $90 \%$ of all tried inmates. This corroborates the general view formed above that, in their vast majority, the Colony's criminals were offenders against the sanctity of property.

8 The European as well as Indian female population stayed on the right side of the law without a single exception - or at least they avoided being caught and sent to prison. This was not the case with Chinese women. No fewer than 103 of them had a taste of prison life during the year 1882. The most significant figure regarding Chinese women prisoners concerns a category of crime in which they seem to have excelled, beating even Chinese men - 'Child Stealing, kidnapping, and buying and selling of human beings'. Unsurprisingly, the only two classes of crimes where British males were more numerous offenders than their Chinese or Indian counterparts were 'Breach of military and naval discipline' (44 European prisoners against no Chinese and no Indian); and 'Misconduct of 
a private or public servant, negligence, desertion' (16 Europeans, 13 Indians, and 11 Chinese). 'Piracy', however, was almost exclusively the preserve of the Chinese male offenders: out of six 'pirates' awaiting trial, only one was categorised as 'European', but he was in fact an Indian lascar. ${ }^{8}$

\section{Flogging, queue cutting, etc.}

9 By a peculiar set of circumstances the colony was settled before Britain had legal title of the island. This created a legal vacuum of some twenty-nine months between the actual taking of Hong Kong (January 1841) and the Queen's Order in Council of $1^{\text {st }}$ June 1843 which gave effect to the legal arrangement stipulated in the Treaty of Nanking. During this period, the practice arose to judge Chinese criminals according to a process of English law, but to sentence them according to Chinese usage. In 1844 this hybrid practice was written into colonial Ordinance 10 of the year 1844 (Section 25), and from then on it became a source of legally-binding double standards. The punishment of chinese offenders was the area most obviously affected by this legal peculiarity which lasted for at least three decades until 1875, when the 1844 Ordinance was finally repealed, though its tradition continued to live on. ${ }^{9}$

Flogging was by far the most common form of punishment. The prevalent crime being larceny, its punishment in England was commonly by way of a fine. In Hong Kong Chinese culprits were usually too poor to pay fines, and they were generously beaten instead. All, or nearly all, were flogged, the number of blows varying from 20 to 100. Few only received a hundred, many had forty or fifty, the latter number being the most common. These are given in public. The criminal with a label on his back, written in Chinese characters, was conducted from the prison to the whipping stand at the west of the Upper Bazaar, and there underwent the sentence of the law, and returned again to prison. ${ }^{10} \mathrm{In}$ England, flogging was abolished in 1861 for male offenders over $16 .{ }^{11}$ In Hong Kong the Europeans continued to be favourable to flogging, and even to public flogging, as all the offenders submitted to it were Chinese. In 1865 , however, a few years after public flogging had made its final exit from the home panoply of deterrents, a European was sentenced to flogging in public. This prompted an immediate, if short-lived, change of heart among the European community. ${ }^{12}$ In fact, public floggings continued unabated, and hundreds more Chinese backs were lashed in subsequent years. The colonial judiciary was largely responsible for retaining and prolonging the punishment far beyond what many at home had seen as its useful life.

I am bound to state [wrote Chief Justice Snowden in 1877] that although I have ever considered the punishment brutal, and brutalising, unfit for a large, high-grade, civilised community, practical results have brought me, most unwillingly, to the conviction, that for a country where the criminal classes are far less humanised, flogging is practically useful. ${ }^{13}$

Cutting the offenders' queues was an unheard-of punishment in common law jurisdictions. Chinese men traditionally shaved the top of their heads and wore their hair in a long plait hanging down behind. This queue was often so long that is was often used as a rope by convicted criminals to commit suicide by hanging themselves in prison on the eve of the execution. The punishment of queue-cutting was introduced in early as 1844 , as a useful expedient once it was realised that the Chinese dreaded it as shameful. But the punishment remained unsanctioned by any law of the Colony for as long as it 
continued in existence. Similar cases of officials - including governors - taking their liberty with existing home laws regulating punishments, or simply making them up as they went along, were by no means infrequent, particularly in the early decades of the Colony. This does not mean that the governors acted willfully outside the law, since they were themselves the executive sources of local Ordinances. But these cases reflect the exploratory nature of early colonial governance, at a time when improvisation was an unavoidable part of obeying the general guidelines set by the home government.

Branding - one of the four main non-custodial sentences with mutilation, the pillory and the stocks - had virtually ceased to exist as a form of punishment by the early $19^{\text {th }}$ century. The pillory was all but abolished in 1815; and the stocks by the middle of the century. ${ }^{14}$ In Hong Kong, however, branding was introduced in 1845 as a source of punishment by Ordinance $\mathrm{N}^{\circ} 1$. Upon the objection of the home government, it was subsequently restricted as a punishment for members of the Triads (criminal secret societies).$^{15}$ But in practice, it continued being applied to a broader range of offenders for at least two decades. ${ }^{16}$. Whilst the pillory does not seem to have been much used in the colony of Hong Kong, the stocks were used extensively on Chinese offenders throughout the period for minor offences, as a shaming adjunct to flogging.

\section{Transportation and the hulks}

13 Before the police was invented as an institution (by the Metropolitan Police Act of 1829 and the Municipal Corporations Act of 1835), policing was largely, if hopelessly, left to magistrates. And prior to the Gaols Act of 1823 and the vast prison-building programme that followed in the 1840s, a prison was essentially a place where suspected offenders awaited trial, not a place where they served their sentences. With no prisons to go to once convicted, thousands of pre-1830s criminals awaited transportation in the hulks. ${ }^{17}$

Transportation was naturally favoured by the authorities as the most economical form of punishment. The insanitary conditions in the hulks exposed by The Times in 1845 led to a prompt dismantling of the hulk system at home. In Hong Kong, the Ordinance abolishing transportation came into force only in 1887. Occasionally death sentences were commuted to transportation for life. The punishment was unusual for Chinese offenders. Typically it was European criminals who were transported to Van Diemen's Land (Tasmania). Other common destinations from Hong Kong were Penang, and Labuan, (a tiny island off the North coast of Borneo). In Hong Kong, there was only ever one single hulk in use - the Royal Saxon. This ship had been purchased in 1863 to serve as an alternative prison pending the rebuilding of the Victoria gaol. The experiment proved a serious embarrassment to the government. Of the 280 convicts awaiting transportation, many died of disease, and 36 drowned as they tried to escape. ${ }^{18}$

\section{Hard labour and the death penalty}

With the decline of transportation as a form of punishment between 1840 and 1867 in England, incarceration became the principal punishment against offenders. The Penal Servitude Act of 1864, the Prisons Acts of 1865 and 1867 had all followed the recommendations of the 1863 Royal Commission on prison reform. Their three main effects were to strengthen the element of deterrence at the expense of rehabilitation, to 
spread the use of separate cells in local prisons as in the national penitentiaries, and to centralise the administration of prisons away from local communities and the Justices of the Peace. Most of what was in force in England by way of prison regulation was assimilated and incorporated into the Prison Ordinance of 1885, which overhauled Hong Kong's previous piecemeal legislation on the subject. ${ }^{19}$

The first Prison Ordinance of $20^{\text {th }}$ September 1853 had opened a period when the prison was used as one of the tools in the panoply of punishments and deterrents, rather than a depot for debtors and prisoners awaiting trial. The prisoner population grew from under 300 in 1856 to over 650 in 1862, and fluctuated around the 600 mark for the following two decades. The Hong Kong Gaol Committee Report of 1876 formed the basis for the revised Regulations for the Gaol. The different classes of hard labour punishments are spelt out in it with graphic precision. They included the shot-drill (a drill lasting three or four hours, with a weight lifting charge of $32 \mathrm{lb}, 24 \mathrm{lb}$ or $18 \mathrm{lb}$, depending on the seriousness of the offence); the crank (a revolving disk invented in 1847, to which a regulated pressure was applied, and which prisoners were required to turn a set number of times a day); oakum picking (pulling old rope apart to produce a material used for caulking and sealing joints on ships); stone-carrying (the carrying by two men of 90lb. stones hung on bamboo poles); stone-breaking (where $11 / 2$ bushel was the standard daily task). The general drift in the evolution of hard labour as a punishment of crime had thus been away from immediate usefulness (building roads, etc.) to a form of harsh exercise that dissociated the pain of the work from its usefulness for society. It was meant to punish while helping to reform the character by enforcing discipline, work habits and obedience. ${ }^{20}$ The passing of the 1885 Prison Ordinance represented a further turn of the deterrence screw. It made the regulations even harsher, which led to serious disturbances in the Victoria Gaol. ${ }^{21}$

Death remained the normal punishment for murder and for most crimes of violence throughout the period. With increasing technical efficiency, the Hong Kong gallows, which had had a sad history of bungled executions, eventually became a reliable instrument. Executions took place in public, and up to the 1875 Report on Crime they usually attracted large crowds. The last public execution occurred in 1893, but by then a 'public' execution meant an execution at which only representatives of the Military and Police were in attendance. The first truly 'private' execution took place in 1895, in the compound of the gaol itself. ${ }^{22}$

\section{Hong Kong's specific crimes: Opium and piracy}

The question of opium, when dealing with Hong Kong criminality, is not just unavoidable - it is central to the discussion. Paradoxically, the Treaty of Nanking mentioned neither opium nor the commercial status of Hong Kong. A whole year of further negotiations proved necessary for Britain and China to agree the provisions of the Supplementary Treaty signed on October 8,1843 . But no agreement was reached on the opium trade itself. The import of opium continued to be illegal from the Chinese point of view. Exports of the drug from India continued to be legal from the British point of view. In the absence of any stipulation in the Supplementary Treaty, the practice which developed and which continued until 1886, was 'a parallel system of informal regulation', or 'a tacit agreement to avoid the facts' ${ }^{23}$ By this arrangement, British opium traders were not allowed by the Chinese authorities to trade directly in the five newly-opened Treaty ports, and neither were the British Consuls at the Treaty ports nor the Hong Kong government supposed to 
help them break the rules of the Empire. Needless to say, a host of well-paid unofficial runners offered themselves to bridge this legal gap in the treaty and the geographical gap between the opium ship anchorages and the cargoes' final destination. The officials of both countries dutifully averted from what had become an unavoidable feature of international trading life. Once induced by the silence of the Supplementary Treaty, this act of fact-denial on a grand scale was allowed to continue until the convention of Cheffoo in 1876 and its ratification ten years later in 1886. Meanwhile the drug trade had flourished, untrammeled by any other rules than those of supply and demand. It had entered a period of forty-five years during which it knew no law, and paid no tax. A consequence of this bizarre state of affairs, unofficially sanctioned as it was by both China and Britain, was that Hong Kong's two main opium dealers Jardine, Matheson \& Co. and Dent \& Co., had largely become independent principalities of their own, with the unavoidable result that whenever they had to defend their ships and cargoes, they had to take the law into their own hands since the Hong Kong government could not to do it for them, Britain being bound by the commercial Treaty regulating exports to China.

Much as its derivatives today, opium was an excellent cash-equivalent. Opium ships therefore were attractive targets for criminals, and many came to grief at the hands of pirates. ${ }^{24}$ It was in the nature of most attacks or attempts committed by pirates on private merchants' opium ships to remain unrecorded in the official histories of the Colony, the opium firms having no incentive to report losses of cargoes or damage to ships, and their ships usually possessing the required armament on board to defend crew and cargo. The cases of piracy officially recorded in the early years of the Colony were usually acts of aggression on passenger- as well as non-opium-carrying merchant ships. No amount of capital punishment seemed to deter the highly organised gangs of pirates until, in the 1850s and 1860s, the Royal Navy cooperated with the Police to bring about the destruction of several notorious pirate fleets. ${ }^{25}$

The impact of opium-smoking itself upon the Colony's criminal activity was more circumscribed and benign, but it led to endemic corruption. An 'Opium Farm' system developed whereby the officially appointed Opium Farmer found himself in the interesting situation of being both a private fund-raiser for the government and a dispenser of influence to the divan owners. This unique role created endless opportunities for corruption. ${ }^{26}$ The drug continued its legal life in the Colony until the Second World War. In England, opium had acquired the status of a 'poison' under the 1868 Poisons and Pharmacy Act, and it had been criminalised in 1920 and 1923 with the passing of the Dangerous Drugs Acts. ${ }^{27}$

\section{Brothels and contagious diseases}

21 The early Colony was a rich breeding ground for brothels: it had a disproportionately large population of single men, both European and Chinese; and there was no want of destitute Chinese girls, or of converted pirates who knew how to make a fortune from pimping and owning brothels. ${ }^{28}$ Back at home until the 1860s, sex outside marriage was reprehensible, but - not unlike drinking - it was illegal only if it disturbed the peace. This was the view in Hong Kong also. The authorities regarded prostitution as an unavoidable evil and treated it with benign neglect so long as it did not disturb the peace. Sensibilities started changing when a fear developed that if the armed forces were to catch V.D. (euphemistically called the 'Havana flu') at the rate the epidemic had spread during the 
Crimean war, the defence of the British Empire might become problematic. From then on the focus of attention was on venereal disease, and it led to Parliament passing the Contagious Diseases Acts of 1864, 1866 and 1869. The acts empowered plain-clothes policemen to subject suspected prostitutes to forcible internal examination, and to imprison them if they were found to carry the disease. ${ }^{29}$

The tenure as Governor of Hong Kong of an enthusiastic Benthamite, Sir John Bowring (April 1854-May 1859), coincided with many of the worst episodes of official 'lawlessness' in the annals of the Colony. He introduced measures which, though they bore the hallmarks of illegality, were in fact a local anticipation of the Contagious Diseases Acts which would be voted by the British Parliament ten to fifteen years later. Bowring and his men first taxed the brothels in order to create a fund used to look after sick prostitutes. ${ }^{30}$ He also imposed the registration of Hong Kong brothels and the medical treatment of prostitutes who, upon forcible examination, were found carrying the disease. Whilst these measures caused not a little moral anxiety among the officials of the Foreign and Colonial Offices, they were not ordered to be rescinded. ${ }^{31}$ Subsequently the batches of reforms introduced in England by the Contagious Disease Acts had no difficulty in being adapted to Hong Kong's circumstances, since they had existed in practice long before that legislation. In order to bypass the particular cultural difficulty encountered in forcing Chinese women to undergo intimate medical examination, a Hong Kong version of the law was devised. It made it compulsory for all brothels to be registered, but in practice only those patronised by the European population were regularly inspected for medical purposes, the others becoming known as 'sly brothels'.

Many viewed forcible inspection of prostitutes for medical reasons as morally reprehensible as it was deemed to be an infringement of their personal liberty. Gradually their views prevailed and the pendulum swung again from a utilitarian to a more idealistic and moralistic standard of legislation. The Contagious Diseases Acts were suspended in 1883 and finally repealed in $1886 .^{32}$ The result of the repeal rapidly showed in official statistics. In ten years, admission of soldiers to hospitals for V.D. had doubled, and half the Indian army had become infected. ${ }^{33}$ Hong Kong again had its own peculiar way of avoiding the worst effects of the repeal. London no longer allowed either the registration of brothels or the medical examination of prostitutes. The Hong Kong Governor pretended to go along with this, and the Colony repealed its own Contagious Disease Ordinance in 1889. At the same time it was agreed with the Colonial office that 'Magistrates should be empowered to close down the brothels to which the police drew their attention'. The moralists at home were delighted. Meanwhile the Hong Kong police were privately instructed not to draw the magistrates' attention to those brothels that continued the practice of allowing their girls to be examined. ${ }^{34}$

\section{Child-stealing and domestic servitude}

Kidnapping for a ransom had been known everywhere, but child-stealing seemed to be specifically rooted in traditional Chinese culture. In the early days of the Colony judges equated this culture-specific crime - stealing young women for domestic service; and kidnapping boys for adoption - as instances of abhorred slavery and they meted out the severest punishments to offenders, including the death sentence. Gradually, however, the Chinese population of Hong Kong developed a social elite of its own, based on commerce, thrift, and mutual help. Only then could the local community reach out to sufficiently 
influential members of the colonial government and impress upon them that the Chinese traditions should be more fully recognized. Differences did exist between the honourable Chinese custom of taking on young girls as future concubines and the crime of human bondage. Governors like Pope Hennessy listened with sympathy to the arguments the Chinese put forward. The sowing of these novel ideas by the Chinese elite led to the foundation of Po Leung Kuk Society. The mission of this charity was to rescue girls and boys from destitution or from the clutches of disreputable or immoral relatives or childstealers and to educate them. In the first four years of its existence the Society rescued 2,751 children and 5,543 from 1888 to $1895 .^{35}$ It was a great success and an early example of Britain's recognition of the need to bend certain home rules to accommodate peculiar local customs.

\section{Gambling and corruption}

For a Victorian, a successful gambler was a walking scandal. To be both idle and rewarded for one's idleness was perfectly intolerable. In the Colony of Hong Kong the situation was aggravated by the fact that gambling among the Chinese was endemic, though any thought of legalising gambling, in order better to control it, was anathema to the Colonial Office. At home, the Betting Houses Act of 1853 prohibited ready-money gambling with bookmakers, and further legislation in 1874 together with the Street Betting Act of 1906 sought to contain street-betting. ${ }^{36}$ As early as the 1850s, Hong Kong governors had requested the authority to license gambling establishments. This was consistently refused until 1867 when, under the governorship of Sir Richard MacDonnell, another cleverlyworded ordinance ( $\mathrm{N}^{\circ} 9$ of 1867 , Sec. 18) was designed, on the face of it, to ensure 'the gradual control and ultimate suppression [of gambling]'. In fact the Ordinance gave the colonial government full discretionary powers about gambling in the Colony. ${ }^{37}$ Immediately, gambling dens were licensed, and in the same way as Hong Kong had an opium farming system, it now developed a gambling farming system. This monopoly soon brought huge revenues to the Colonial Government, which in turn redistributed a portion to Chinese charities. ${ }^{38}$ This bold experiment in licensed gambling, however, proved shortlived, and Sir Richard MacDonnell had to put an end to it in January 1872, following a barrage of protest from London.

Cases of serious crimes committed by members of the Police under the heading 'Bribery and Corruption' form a long catalogue of misdemeanours, from squeezing divan-owners, gamblers and prostitutes to corruption of witnesses, protection of pirates and other criminals in return for information and graft, extortions of all descriptions, embezzlement, etc. The most extensive Police purge occurred in 1898, following the dismantling of the latest Police bribery syndicate. Those dismissed and prosecuted in that case included fourteen senior European Police Officers, and dozens of constables. As a result of this scandal, the Ordinances were amended to make the offence of bribery punishable where it had previously largely remained unpunished. ${ }^{39}$

In an attempt to summarise what the British and the rule of law had achieved in the Colony of Hong Kong from its beginning to the year 1898, Norton-Kyshe wrote : 
Even with a knowledge of British enterprise, it would be a tax upon one's credulity to believe that, within the comparatively short space of time which has elapsed since Hong Kong was incorporated within the British Dominions, such rapid strides in development could have taken place. All this is the result of British energy, British enterprise, and English Law, accomplished under the benign rule of Her Most Gracious Majesty, Queen Victoria. ${ }^{40}$

This brief study suggests that whilst there was indeed progress in the way that Hong Kong crime was reined in during the period, progress did not occur simply out of Victorian historical necessity. It depended on a variety of complex factors and individual decisions, on personal relationships and on an ever-changing structure of colonial governance. From this point of view, it is likely that the main factors affecting the development of the rule of criminal law and the punishment against offenders in Victorian Hong Kong are all to be found at the crossroads of three different kinds of history. It may be useful, in concluding this exploratory paper, to outline the characteristics of this ideal crossroads where all relevant material would at last be revealed.

The first kind of history is the socio-political history of how British nineteenth-century criminal statutes came into existence, and how, from one period to the next, definitions of crime and prescribed methods of deterrence varied according to where the pendulum had reached in its swing from one extreme and the other - from Benthamite utilitarianism at one end, aiming at containing vices and crimes in society with maximum efficiency and at the lowest cost, to moral idealism at the other end, emphasising above all the sanctity of personal freedom and the need to reform offenders.

The second kind of history is that of the relationship between the Colonial office and colonial administrators in general, and the Hong Kong governors in particular. This is a story that would account for the varied factors, - of time, location, persons, individual skill, and of changing patterns of administrative structure whose ceaseless interplay gave governors and their local teams more or less elbow-room in the application of the British law and in the execution of orders received by H.M. ministers.

31 The third kind of history is that of the evolving relationship between the ruling colonial newcomer and the colonised population. However, because the natives do not speak - or if they speak they cannot be understood - this history would need to include developments borrowed from the discipline of anthropology, which could give them the voice which the early colonial system did not allow them to have. (Indeed the whole problem of interpretation and of interpreters, central as it is to the discipline of History - was also one of the most crucial practical problems in the Hong Kong courts and government during the whole of the Victorian period). Even a cursory study of how the tacit recognition of child-stealing had the effect of both by-passing the penalty of colonial law and strengthening the voice of a colonised people that once was altogether voiceless, shows that the main task of the historian who interprets past facts as they are found recorded in written documents, should be buttressed by the work of the anthropologist, who interprets unwritten customs and cultures as they show through behaviour and oral lore.

32 At the crossroads of these three kinds of history, and out of the vast and disparate corpus that together they would form, it might at last be possible to recognize and assemble into a coherent pattern those elements best calculated to make our contemporaries understand the crimes committed and the punishments inflicted or devised long ago on a 
remote Chinese corner of the Victorian Empire. The future being essentially uncertain, we might then have the ultimate surprise of discovering that what appeared in this exploratory paper as a fairly representative sample of the British art of 'muddling through' was after all a perfect example of planned progressive action. On current evidence, though, this seems rather unlikely.

\section{NOTES}

1. Frank WELSH, A History of Hong Kong, London: Harper Collins, 1994, quoting FO705/49, p. 162. For the earlier standard History of Hong Kong, see George B. ENDACOTT, A History of Hong Kong, London: Oxford University Press, 1973.

2. Ibid., p. 159.

3. Ibid., p. 158.

4. The primary sources analysed here were found in Hong Kong Colony Administrative Reports, 1882, Hong Kong: Government Printers, 1883. See in particular Notification $\mathrm{N}^{\circ} 5$ and Notification $\mathrm{N}^{\circ} 83$. Another primary source consulted for this paper is the collection of British Parliamentary Papers, China 24, 1846-1860, British Parliamentary Papers, China 25, 1826-1881, and British Parliamentary Papers, China 26, 1882-1889, 3 volumes, repr. Shannon: Irish University Press, 1971.

5. John BRIGGS, Christopher HARRISON, Angus McINNES \& David VINCENT, Crime and Punishment in England: An Introductory History, London: University College Press, 1996, p. 139.

6. Welsh, op. cit., p. 253.

7. Briggs, op. cit. p. 131.

8. James William NORTON-KYSHE, The History of the Law and Courts of Hong Kong from the Earliest Period to 1898, (1898), 2 volumes, Hong Kong: Vetch and Lee Limited, 1971, vol. II, p. 352. Hong Kong historical scholarship is heavily indebted to NORTON-KYSHE who was the principal Victorian chronicler of the colony. The primary sources he used were principally the Court's archives and other legal and judicial documents dating back to Hong Kong's earliest years. Most of this primary material was subsequently destroyed. On this point, see Peter Wesley SMITH, 'Research Material for Hong Kong Legal Studies', in Alan BIRCH, Y.C. YAO \& Elizabeth SINN, Research Material for Hong Kong Studies, Hong Kong: Centre of Asian Studies, 1984, pp. 336-340.

9. NORTON-KYSHE, op. cit., vol. I, p. 20.

10. Ibid., p. 31,

11. BRIGGS, op. cit., p. 159

12. NORTON-KYSHE, op. cit., vol. II, p. 90.

13. Ibid., vol. II, p. 265.

14. BRIGGS, op. cit., p. 159.

15. NORTON-KYSHE, op. cit., vol. I, pp. 73-74

16. Samson CHAN, Development of the Hong Kong Penal Policy and Programme under the British Administration, 1841-1944, Unpublished Diss. for the Degree of M.A. in Public Order, University of Leicester, in association with the School of Professional and Continuing Education of the University of Hong Kong, 1944, p. 35.

17. BRIGGS, op. cit., p. 162.

18. NORTON-KYSHE, op. cit., vol. II, p. 136

19. CHAN, op. cit., p. 57. 
20. Ibid., pp. 39-40

21. The resulting prison riots were the most serious recorded in the period. See NORTON KYSHE, op. cit., vol II, p. 395.

22. Ibid., vol II, pp. 451-452 and 457-459.

23. John King FAIRBANK, Trade and Diplomacy on the China Coast: The Opening of the Treaty Ports, 1842-1854, (1953), Stanford: Stanford University Press, 1969, pp. 135, 142, and 133-151. This scholarly work on the opening of China by the American historian of China remains unmatched in depth of research and insight.

24. NORTON-KYSHE, op. cit. vol. I., p. 139-142. On cases of pirates killing entire crews of opium ships, see also Alain LE PICHON, Aux Origines de Hong Kong, Paris: L'Harmattan, 1999, pp. 482-483.

25. P. J. MELSON, The History of the Royal Navy in Hong Kong, 1841-1997, Edinburgh: David Tait, 1997, p. 15-16. See also Norton-Kyshe, op. cit., vol I, p. 264.

26. WELSH, op. cit., p. 172.

27. BRIGG, op. cit., pp. 204-206.

28. WELSH, op. cit., p. 152 and p. 558.

29. BRIGGS, op. cit., pp. 198-199.

30. NORTON-KYSHE, op. cit., vol I, p. 133.

31. WELSH, op. cit., pp. 261-262.

32. BRIGGS, op. cit., p. 199.

33. WELSH, op. cit., p. 264.

34. Ibid., pp. 256.

35. NORTON-KYSHE, vol. II, pp. 197-198. On the rise of a Chinese elite in the late Victorian Hong Kong, see Elizabeth SINN, Power and Charity: The Early History of the Tung Wah Hospital, Hong Kong, Hong Kong: Oxford University Press, 1989. On the muitsai question, see Maria JASHKOK, Concubines and Bondservants : A Social History, Hong Kong: Oxford University Press, 1988.

36. BRIGGS, op. cit., p. 200.

37. NORTON-KYSHE, vol. II, p. 114.

38. SINN, 1989, op. cit. p. 38.

39. Ibid., pp. 500-501. On the corruption of the police during the period, see: Colin CRISSWELL \& Mike WATSON, The Royal Hong Kong Police (1841-1945), Hong Kong: Macmillan, 1982. See also Kevin SINCLAIR, Asia's Finest : An illustrated Account of the Royal Hong Kong Police, Hong Kong: Unicorn, 1983.

40. NORTON-KYSHE, op. cit., vol. II, p. 554.

\section{ABSTRACTS}

In 1842, the Treaty of Nanking gave the island of Hong Kong to the British Crown. The new settlement immediately attracted a population of poor Chinese who flocked there in the hope of making a better living than on the mainland. Not surprisingly, crime was rampant on the fringe on the new colonial city, and offenders had to be tracked down and punished. This paper investigates the nature of the crimes committed in Hong Kong during the Victorian period, the evolving panoply of punishments designed to rein them in, and the way in which both the common law and the colonial governments adapted to fight types of criminal activity they had never met before. 
En 1842, le Traité de Nankin cédait l'île de Hong Kong à la couronne britannique. La nouvelle colonie attira aussitôt une population de Chinois pauvres qui s'y installèrent en grand nombre dans l'espoir d'une vie meilleure qu'en Chine. Comme il fallait s'y attendre, le crime se développa rapidement sur les marges de la cité coloniale, et il fallut repérer et punir les criminels. La présente étude s'attache à recenser et à comprendre la nature des crimes commis à Hong Kong pendant la période victorienne, la panoplie des châtiments destinés à les punir, et la manière dont la common law et les gouvernments coloniaux s'adaptèrent dans leur combat contre des formes de criminalité qu'ils n'avaient auparavant jamais rencontrées.

\section{AUTHOR}

\section{ALAIN LE PICHON}

Université Paris IV-Sorbonne 